\title{
Response to Amy Pollard
}

By Judith Okely (University of Oxford)

This study provides important insights into doctoral students' fieldwork experiences. The interviewer admits that her experience working for the Samaritans tended to steer the interviewees into negative aspects. We learn a lot about the stress and the selfcriticism experienced by students. Themes are categorised by emotions as opposed to process. All together the 16 interviewees were from just three anthropology departments. Surprisingly, the interviewees' gender was neither recorded nor problematised. I noted some 13 named women and three men of whom one was not formally interviewed. The supervisors seemed predominantly male. Despite the fashionable Butleresque insistence that sex/gender is mere changeable performance, there are long-term gendered legacies regarding education, experience and identity. Indeed, a number of women described being vulnerable to sexual harassment, stalking, if not rape in the field. Supervisors seemed sometimes to be gender presumptive. There was an example of breathtaking sexism and arrogance by a male supervisor who arrived in the field with his own informants and expected the woman student to accommodate and cook for them for an unlimited period. Mercifully, we are not given details of the worst abuse of power which I know occurred in the recent past, namely male supervisors demanding droit de seigneur of a female student in the field. The painfully detailed self-critique, so often apparent in the accounts, is also a tendency I have noted in women students. The example of a male postgraduate, Euan, is also marked by poignant self-questioning.

It is a surprise how much the postgraduates seemed to depend on emails and repeated replies from supervisors back home. The latter are increasingly faced by clogged Inboxes from other new bureaucratic demands. I wonder how far in-depth field participant observation can develop if the fieldworker is expecting regular online supervision by someone neither participating nor observing. With easier travel and perhaps for those with extended doctoral fieldwork behind them, there is what Helena Wulff (2002) calls "yo-yo fieldwork". But here, the novice fieldworkers punish themselves for taking short breaks. I once believed my contemporaries with "authentic exotic" fieldwork had "really" lived in isolation for over a year. In fact some had taken luxuriously extended holidays in places like Goa.

Aspects of fieldwork which interviewees regarded as failures and sources of guilt were potentially key avenues for knowledge. For example, interviewees wisely responded to new topics and the peoples' own agenda. They punished themselves for mistakes. But you only learn the unknown rules when you break them. In my dialogues with over 20 anthropologists, all but one switched focus in the field. They responded to what they encountered rather than sticking to prior hypotheses to be 
tested at all costs. Fieldwork did not and cannot go to plan. There are creative discoveries to follow through. Agar's (1980) open-ended "funnel" remains the most productive approach. Do not filter in advance.

Agar also affirms that the fieldworker brings his or her total past experience into the field. This may be profound, banal, scholarly reading or embodied knowledge. When writing up, some students productively transformed some of their fieldwork traumas. Previous participatory experience, such as in NGOs, was probably more useful than deskbound academia. I also found that my pre-anthropological experience of participant observation in Western Ireland with my then partner gave grounded conviction when later finding neither methods courses nor texts (Okely 2008).

It is shocking to learn the extent to which postgraduates considered their prefieldwork preparation inadequate or inappropriate. Yet "methods training" has been imposed by government-sourced funders for nearly two decades. In the late 1980s, the UK's Economic and Social Research Council (ESRC) originally suggested a one-sizefits-all for social science methods. Fortunately, this was defeated. But subsequently thousands and thousands of pounds were ring-fenced for doctorates specialising in quantitative methods alone. I attended a supposedly inclusive methods Research Council workshop in the mid-1990s where it became embarrassingly apparent that we invited ethnographers, mere "qualitatives", were only there as window dressing. The agenda had been set. Social anthropology had already lost a number of guaranteed ESRC doctoral awards after polytechnics (with only one anthropology department) were transformed into universities. The new compulsory methods training courses imposed ever more quantitative specialisms, with ethnography just an afterthought. In the 1980s, when lecturing on compulsory methods to undergraduates in the Essex Sociology department, I noted my predecessor's reading list advised that students merely read novels for qualitative methods. Even now, little recognition is made that fieldwork is not simply a cerebral exercise, but also embodied. The interviews here and those I have conducted confirm this (Okely 2007b).

Ironically, while the CIA and US military are trying to recruit anthropologists, especially with British traditions, e.g. at the special meeting at the 2006 American Anthropological Association (AAA) conference in San Jose, the UK funding councils have for years undervalued the uniqueness of long-term intensive fieldwork. Only when counter-terrorism studies recognised the importance of "culture" and "embedded" fieldwork did a UK Research Council initially accept controversial covert funding for anthropological fieldwork in allocated places. Fortunately, John Gledhill, as head of the Association of Social Anthropologists of the UK and Commonwealth (ASA), took an uncompromising stance on this project which risked all anthropologists being labelled government spies.

It is amusing to note how the non-ESRC postgraduates interviewed here were hostile to imposed quantitative courses. The tail has wagged the dog. I witnessed the same at my previous university and was disappointed that efforts were made by a Departmental Head to block anthropology postgraduates doing my course on film making, which was funded by C-SAP (the Higher Education Academy Subject Network on Sociology, Anthropology, and Politics). It was bizarrely argued that students needed quantitative training for future employment, while camera skills would be "useless". Pollard mentions "rumours" of a department where staff field notes were presented for student scrutiny. I always brought in my handwritten files for my Ethnography course at Hull. 
There are some excellent insights in this article which could be elaborated: the postgraduate who recognised that she was jumping too soon into analysis and premature conclusions. Given Pollard's admission to eliciting negative responses, I am convinced there was also a wealth of life changing and inspiring experiences. Some recognised that all their material was eventually seen to become relevant. They had in effect pursued a funnel approach. Ultimately, some recognised that no training, however extensive, can ever fully prepare the fieldworker. Again I have found the unexpected and unpredictable to be crucial in my dialogues with anthropologists.

Postgraduates should be encouraged to value their own resources. Individual personality, biography, ethnicity, nationality and gender will all have specific implications. The anthropologist should recognise that seeming weaknesses, along with incomer naivety, are qualities to explore creatively. The traditional, often masculinist mask of competence has to be dropped. Regrettably, the interviewees felt pressurised to conceal past field difficulties both from their peer group and their supervisors. The sharing of experiences, dramatic or commonplace, is a resource for enhanced knowledge. Some confessed to finding the return more alienating than their departure. May I warn post docs that moving to a lectureship may be more disturbing than any fieldwork. Some postgraduates found personal relationships were rendered vulnerable by absence. Again gender might be of significance if women more than men leave a partner behind. But gone are the days when at Durham University I was advised that as a woman I had to break up with my partner in London if I wanted the permanent lectureship (Okely 2007a)!

Advance insights into others' accounts offer cross-cultural examples and possibilities vital to understanding that fieldwork has commonalities. There are both benign but informative collected accounts and also more traumatic ones concerned with conflict (Nordstrom and Robben 1995), sexual relations and regrettably rape (Kulick and Willson 1995). The sociological positivist's clichéd critique that anthropological intensive fieldwork is "reliable" but not "valid" should be abandoned. Number crunching skills through enforced training are less important than detailed case studies, commonalities and comparisons. There is a wide range of possibilities when living and studying both within and beyond the anthropologist's known culture. Ultimately, the fact that all cannot be predicted nor formulated in advance is anthropology's strength. It emphasises originality, not merely that which is repeatable.

\section{References}

Agar, M. 1980. The professional stranger: An informal introduction to ethnography. London: Academic Press.

Kulick, D. and M. Willson, eds. 1995. Taboo: Sex, identity and erotic subjectivity in anthropological fieldwork. London: Routledge.

Nordstrom, C. and A. Robben, eds. 1995. Fieldwork under fire: Contemporary studies of violence and survival. Berkeley: University of California Press.

Okely, J. 2007a. Gendered lessons in ivory towers. In Identity and networks: Fashioning gender and ethnicity across cultures, eds. D. Fahy Bryceson, J. Okely and J. Webber, 228-48. Oxford: Berghahn.

-------. 2007b. Fieldwork embodied. In Embodying sociology: Retrospect, progress and prospects, ed. C. Shilling, 65-79. Oxford: Blackwell. 
--------. 2008. Knowing without notes. In Knowing how to know: Fieldwork and the ethnographic present, eds. N. Halstead, E. Hirsch and J. Okely, 55-74. Oxford: Berghahn.

Wulff, H. 2002. Yo-yo fieldwork: Mobility and time in a multi-local study of dance in Ireland. Anthropological Journal on European Culture 11, 117-36.

\section{About the author}

Judith Okely is Emeritus Professor of Social Anthropology, University of Hull, and currently Deputy Director of the International Gender Studies Centre, Queen Elizabeth House, and Research Associate, School of Anthropology, University of Oxford. Her books include The Traveller-Gypsies (1982), Simone de Beauvoir: A rereading (1986), Anthropology and autobiography (1992) (co-edited), Own or other culture (1996), Identity and networks: Fashioning gender and ethnicity across cultures (2007) (co-edited), and Knowing how to know: Fieldwork and the ethnographic present (2008) (co-edited). Her research interests encompass Fieldwork practice, Gypsies, feminism, autobiography, visualism, landscape representations, and the aged, mainly within Europe. She can be contacted at j.m.okely@hull.ac.uk. 